\title{
ГІДНЕ ПОЦІНУВАННЯ ФЛАГМАНА ПРОФЕСІЙНОЇ ВИДАВНИЧО-ПОЛІГРАФІЧНОӦ ПЕРІОДИКИ
}

14 лютого на засіданні спеціалізованої вченої ради Київського національного університету імені Тараса Шевченка відбувся захист дисертаційної роботи на здобуття наукового ступеня кандидата наук із соціальних комунікацій Макухи Марини Василівни «Журнал «Друкарство» як тип періодичного видання для фахівців видавничої справи та редагування».

Нині в Україні наявність якісної фахової наукової періодики, що повноцінно та регулярно інформувала фахівців, науковців видавничо-поліграфічного комплексу (ВПК) про новини галузі, наукові досягнення та їх практичне застосування суттєво обмежена в різноманітності, а то й майже відсутня.

В період з 1994 по 2006 рр. науково-практичний часопис ВПК «Друкарство» орієнтувався як на видавців, поліграфістів, так і на книгорозповсюджувачів, й у непростий період становлення України як незалежної держави, практично був єдиним журналом, відомим в українських і закордонних професійних колах та одним з небагатьох, які входили до переліку наукових фахових видань ВАКу України.

Тому враховуючи вищезазначене, об'єктом дослідження Макухи М. В. стали умови створення і етапи розвитку науковопрактичного часопису «Друкарство» в контексті української фахової періодики ВПК протягом 1994-2006 рр.
Серед досліджуваних здобувачкою завдань для реалізації поставленої мети ї визначити роль, яку відігравав журнал у науковій фаховій періодиці незалежної України такі: аналіз стану та тенденцій розвитку вітчизняної фахової періодики в зазначеній період; особливості становлення та основні проблемно-тематичні напрями публікацій часопису із здійсненням його періодизації та типологічного аналізу.

Джерельною базою емпіричного дослідження слугували як архівні документи, наукові праці, нормативно-правові акти, підшивки журналу, так і спогади в різні періоди головних редакторів, членів редколегії ї І. Агаркова, Ф. Мартинюка, О. Мельникова, Б. Никифорука, О. Розума, М. Тимошика.

Методологічна основа роботи базувалась на системному підході з використанням цілої низки методів: історико-оглядового, історико-описового, історико-хронологічного, проблемно-тематичного, контент-аналізу та статистичного аналізу даних.

Дослідження журналу «Друкарство» проводилось в контексті аналізу більше 35-ти спеціалізованих видань ВПК у зазначеній період. На увагу заслуговують такі тенденції фахової газетно-журнальної періодики: середня періодичність ї 51,7 \% виходили 6-10 років та 36,7 \% ї шість разів на рік; середній наклад - 3000-4000 примірників 
(23,3 \%, причому 20 \% редакцій наклад у вихідних даних не оприлюднювали); 53,3 \% періодики була україномовною.

Цікавим $€$ досліджений організаційний аспект діяльності колективу «Друкарства»: крім основних видів (випуск у світ фахових науково-практичних, історичних публікацій; вивчення і задоволення читацького попиту; розв'язання проблем видавничо-поліграфічного, освітнього та національного напрямів), й додаткові участь часопису у спеціалізованих вітчизняних і закордонних виставках, семінарах, конкурсах; інформування про вихід і поширення професійних видань ВПК; надання редакційно-видавничих, виробничих, інтернет-послуг юридичним і фізичним особам тощо.

Також в дисертації проаналізовано такі формальні ознаки та їх вплив на формування стилю часопису, як обсяг, періодичність, наклад, географію авторів, наявність анотацій до статей іноземною мовою (англійською), інформацію про авторів, логічну структуру статей, посилань на літературні джерела, рекламу, інші додаткові послуги редакції.

Здобувачкою при дослідженні діяльності часопису «Друкарство» також виявлено, що в кожному числі видання публікувалось у середньому 25 авторів, причому загальний авторський колектив був представлений близько 650 вченими, фахівцями видавничо-поліграфічної галузі. Також виокремлено основні етапи зміни внутрішньої структури часопису, яка була представлена близько 70-ма найменуваннями різноманітних розділів та більше 1500 публікаціями не лише наукового характеру.

Отже, представлена дисертація та отримані результати дослідження мають величезне практичне значення як для вивчення історії становлення інформаційного забезпечення ВПК України; проблем розвитку вітчизняної фахової періодики, так і для створення підручників, нормативних спецкурсів, семінарів, присвячених фахівцям та науковцям галузі; підготовці систематичних покажчиків змісту періодичних видань та впорядкування бібліографії української видавничої періодики, і як зазначили члени спеціалізованої вченої ради під час захисту, окремі результати дисертації, безсумнівно, мають неоціненну практичну цінність досвіду функціонування часопису «Друкарства» для існуючих і майбутніх професійних видань та науковопрактичних журналів. 